\title{
The Effect Of Planning And Control To Bureaucracy Behavior In The Improving Service Quality On Department Of Population And Civil Registration Dki Jakarta,Indonesia
}

\author{
A.M.Hendropriyono ${ }^{1}$, Suroyo ${ }^{2}$, Aripin ${ }^{3}$ \\ ${ }^{12}{ }^{3}$ High School of Economic Tribuana, Bekasi Major M. Hasibuan Street No. 5 Bekasi Indonesia17113
}

\begin{abstract}
The main problem in this study is the service quality in the Department of Population and Civil Registration Jakarta is considered optimal. Bureaucratic behavior, presumably as a result of poor planning and oversight that cannot be implemented properly. The purpose of this research is to gain any influence planning on the bureaucratic behavior, monitoring on bureaucratic behavior, and the influence of bureaucratic behavior on the service quality and to obtain a new concept for the development of science and useful and can be applied in the community, especially in the Department of Population and Civil Jakarta. The method used in this study is non-experimental survey method with sampling Stratified Random Sampling. Technical analysis is the data used path analysis. Test the validity of the instrument using the Pearson correlation test product moment and reliability of the instrument using Cronbach alpha The results showed that the positive effect the planning on the bureaucracy behavior, oversight positive effect controlling on the behavior of bureaucracy and positive effect bureaucratic behavior on service quality. The findings in this study are not routinely conducted surveillance dimension thus potentially deviant bureaucracy behavior is not optimal to improve the service quality. The implications of this research are bureaucratic behavior is important in improving Service quality.
\end{abstract}

Keywords: Planning, Controlling, and Service Quality and Bureaucracy Behavior

\section{Introduction}

In Indonesia, the perception of civil registration certificate is no more seen as a validation function, while in other countries such as Malaysia, Singapore, civil registration certificate is a record of important events of one's life, such as birth, marriage, and death [1]. By pooling over the Internet on service quality in Population and Civil Registration Department Jakarta produce very satisfactory answer $=10$, satisfied $=25$; unsatisfactory= 45 , and very unsatisfactory $=138$.

Based on a survey conducted on the public a glimpse of the Department of Population and Civil Registration Jakarta . Some of the complaints received from the public to the institution performance in 2012 is known in the following table:

Table1.1.

Type and Number of Complaints Public to Service in Department of Population and Civil Registry Jakarta

\begin{tabular}{|l|l|l|}
\hline No & Complaint Type & Total \\
\hline 1 & The process of handling a complicated deed & 9 \\
\hline 2 & Imposition of charge deed is too high (far above provisions) & 21 \\
\hline 3 & Apparatus Behavior that is less friendly and less responsive & 12 \\
\hline 4 & Completion of matters not on time & 17 \\
\hline & Total & 59 \\
\hline
\end{tabular}

Source: Department of Population and Civil Registry DKI Jakarta 2012

The above data show that the service quality of the Department of Population and Civil Registration Jakarta is still low. This condition is thought to be a result of the bureaucracy behavior of the government and the poor tend to deviate from its function as a public servant. In addition, factors of planning and controlling oversight have not well. For satisfaction, service quality is very important for well managed and a level of excellence to meet the wishes of consumers [2]. Weterson [3], suggests that the essence of planning is an organized effort to consciously and continuously conducted to select the best alternative from a number of alternatives to achieve a certain goal. On the other side, the planning is application of rational of human knowledge of the decision making process which acts as the basis of human behavior. 
Mathis and Jackson [4], states that supervision is a process of monitoring employee performance based standards to measure performance, ensuring the quality of information retrieval performance assessment and feedback that can be communicated to the achievements of employees. Maringan [5] stated purpose of supervision is to prevent and correct errors, irregularities, discrepancies in the implementation of the tasks performed and for the implementation in accordance with a predetermined plan. Previous research studies related to the assessment of the services quality of public sector namely Wisniewski [6]; Rowley [7]; Brysland [8]; Kokku [9]; Munhurrun, [10]; But the result is there is a difference. Some claimed the quality of managed care with good planning and supervision of research include Kokku et al, than some are not successful because of the planning and supervision of them less optimal results Munhurrun et al. Differences in previous research results will be important to examine in the Department of Population an Civil Registry DKI Jakarta. The purpose of this study was to clarify the effect of the planning and controlling oversight of bureaucratic behavior in improving the quality of service on the Department of Population and Civil Registry Office of DKI Jakarta.

\subsection{Planning Concept}

\section{Literature Review}

Robbins and Coulter [11] states that the management functions are planning, organizing, leadership, and supervision. Planning as a tool to measure or standard to conduct monitoring and evaluation. Bintoro [12] states that planning is the process of preparing activities that will be carried out systematically in order to achieve certain goals. In planning basically is setting goals, and strategies that will be used to develop the plan for the coordination of activities. (13).

\subsection{Controlling Concept}

A control can be said to be good if it has the characteristics of an organizational structure in which there is separation of functional responsibilities that suit your needs including authorization procedures and records appropriate to allow a reasonable control [14]. Kontz and O'Donnell [15] states that the supervision and planning closely related.

Terry, [16] suggests supervision is: "Controlling is Determining what is being accomplished that is. Evaluating the performance and, if Necessary, applying corrective measures so that (he performance takes place According to plans. Controlling can be viewed as detecting and correcting significant variations in the result Obtained from planned activities. Kreitner [17] proposed surveillance is: "Its a management function, control is the process of taking the Necessary preventive or corrective actions to Ensure that the organization's mission and objectives are accomplished as Effectively and Effectively as possible "

\subsection{Bureaucratic Behavior concept}

Bureaucratic behavior is underlying value citizenships, social justice, equity, ethics, responsibility, patriotism, openness is the real essence of administration public [18]. Hersey and Blanchard [19] suggests that to predict behavior that is reflected in the bureaucracy activities, or the need to know one's motives in his work. Gibson, Ivancevich, Donnelly [20] states that bureaucratic behavior is an interaction between the individuals in the organization, because of bureaucratic behavior is determined by the individual functions within the organization.

\subsection{Service Quality concept}

Research on service quality has a lot to do with various aspects of multidimensional since long and has been developed by Gro"nroos [21]; Berry [22]; Parasuraman [23]; Brady [24]. The service quality concept has been debated since not match the multidimensional situation throughout the country [25]. They argue that in order to cope with the multidimensional aspect of service quality should be explored further. Measurement of service quality problems in some services sectors have been explored by researchers such as Parasuraman [26]; Koelemeijer, [27]; Vandamme [28]; Parasuraman [29]. Framework for measuring the service quality dimensions of tangibility, reliability, responsiveness, assurance and empathy conducted by Parasuraman [30]

\section{1. Research design}

\section{Research Methods.}

This study is non-experimental, or research method called explanatory survey method, is a research method that is used to explain the phenomenon that was the problem [31]. In addition to describing and explaining the empirical facts encountered in the field, also the effect analyzed of one variable with another variable, in this study using a quantitative approach as the main element. Because of the problems between the studied variables have a causal relationship and the relationship is the effect, then the analysis is a statistical test used path analysis. Descriptive research is research that aims to gain an overview of the level of influence the 
planning, oversight of bureaucratic behavior order to service quality in Department population and civil registration Jakarta.

\subsection{Data Analysis Techniques}

The technique used in this research is the Path Analysis. The population used in this study is the public who have service obtained The Population and Registry at the Provincial level, city, sub-districts and villages. With the following composition:

1. People who have been getting services at the provincial level: 9 .

2. People who have earned service at the city level: 45

3. People who have been getting services at the district level 54 .

4. People who have been getting services the village level: 317.

Sampling technique using "stratified random sampling" is a sampling technique by levels. The meaning of this level is the structural and consists of: the provincial level, city level, district level and village level. At each the population level taken as many as 19\% [32]. Having taken 19 percent of each level the population, the total sample of 80 people. Before instrument disseminated research, performed research instrument first try out (test) against 30 respondents in order to check the reliability and validity, the results of which are qualified research instrument to proceed.

\section{Results}

\subsection{Description Research Objects}

Main tasks department population and registry are administer the registration and recording population of Indonesian citizens and foreigners, with the types of services as follows:

Table 4.1.Types of Service Population and Civil Registration DKI Jakarta.

\begin{tabular}{|c|c|c|}
\hline No & Description & Office Services \\
\hline 1 & Identity Card & Urban Village \\
\hline 2 & Family Card & Urban Village \\
\hline 3 & Reporting Birth & Sub Population \& Civil Registry \\
\hline 4 & Reporting Death & Urban Village \\
\hline 5 & Reporting Arrival & Urban Village \\
\hline 6 & Reporting Removals & Urban Village \\
\hline 7 & Reporting New Arrival & Urban Village \\
\hline 8 & Birth Certificate (General \& Exemption) & Sub Population \& Civil Registry \\
\hline 9 & Death Certificates (General \& Exemption) & Urban Village \\
\hline 10 & Marriage Certificate Indonesian Citizens & Sub Population \& Civil Registry \\
\hline 11 & Deed Divorce Indonesian Citizens & Sub Population \& Civil Registry \\
\hline 12 & Special Birth Certificates & Urban Village \\
\hline 13 & Special Death Certificate & Urban Village \\
\hline 14 & $\begin{array}{l}\text { Marriage Certificate Indonesian Citizens } \text { And } \\
\text { Foreign }\end{array}$ & Sub Population \& Civil Registry \\
\hline 15 & Deed Divorce Indonesian Citizens And Foreign & Sub Population \& Civil Registry \\
\hline 16 & Deed Rename & Sub Population \& Civil Registry \\
\hline 17 & Deed Validation And Recognition Of Child & Sub Population \& Civil Registry \\
\hline
\end{tabular}

(Source: DKI Jakarta Governor Decree, No. 16,2005)

Function of population and civil registration offices of Jakarta is:

1. Registration of births, deaths, removals arrivals and foreign.

2. Registration And Nationals Certificate Issuance And Foreign..

3. Recording Data on the mutation nationals deed and foreign

4. Management and issuance of identity cards.

5. Study bio mutation identification and recording of the population.

6. Management, data presentation and registration information resulting from the population registry.

7. To provide guidance to the administration of the registration and recording of the population.

8. Implementation of the provisions of the registration and recording counseling residents. 
9. Controlling deal with certain rules, dispute settlement residents.

10. Certificate of registration and management of citizen identification.

11. Management reporting seasonal residents.

12. Collection of statistics,

13. Technical guidance for the implementation of a work of subordinates.

\subsection{Hypothesis Test results.}

Under the influence of the path coefficient is known that there are three paths that have proven reliability. Those values can provide evidence that cannot be refuted. Summary of results of analysis of the influence of the path between the existing path variables are as follows:

Table. 4.2

Summary of Research Results Analysis

\begin{tabular}{|c|c|c|c|c|c|c|c|c|c|}
\hline \multirow[b]{2}{*}{ Causal } & \multirow{2}{*}{$\begin{array}{c}\begin{array}{c}\text { Coef } \\
\text { Corel }\end{array} \\
r_{i j}\end{array}$} & \multirow{2}{*}{$\begin{array}{c}\begin{array}{c}\text { Coef } \\
\text { Path }\end{array} \\
\rho_{\mathrm{ji}}\end{array}$} & \multicolumn{3}{|c|}{ Significance Tests } & \multirow{2}{*}{$\begin{array}{l}\text { Coef } \\
\text { New } \\
\text { Path }\end{array}$} & \multicolumn{2}{|c|}{ Levels influence } & \multirow{2}{*}{ Total } \\
\hline & & & $\mathrm{t}$ arithmetic & $\mathrm{t}_{\text {table } 0,01 \& 0,05}$ & information & & Direct & Indirect & \\
\hline $\mathbf{X}_{1} \quad \rightarrow \quad \mathbf{X}_{2}$ & 0,599 & 0 & - & - & cut no path & 0 & 0 & 0 & 0 \\
\hline$X_{1}->Z$ & 0,504 & 0,268 & 2,401 & - & Significant & 0,268 & 0,135 & 0 & 0,135 \\
\hline$X_{1}->Y$ & 0,579 & 0 & - & $0,238 \& 1,67$ & cut no path & 0 & 0 & 0,116 & 0,116 \\
\hline $\mathbf{X}_{2}->\mathbf{Z}$ & 0,579 & 0,432 & 3,878 & $0,238 \& 1,67$ & Significant & 0,432 & 0,251 & 0 & 0,251 \\
\hline $\mathbf{X}_{2}->\mathrm{Y}$ & 0,643 & 0 & - & $0,238 \& 1,67$ & cut no path & 0 & 0 & 0,210 & 0,210 \\
\hline$Z->Y$ & 0,748 & 0,748 & 7,641 & $0,238 \& 1,67$ & Significant & 0,748 & 0,560 & 0 & 0,560 \\
\hline
\end{tabular}

Sources: Primary Data 2012

Based on the analysis starts from correlation coefficient value to determine degree of influence is known that the initial concept of the influence planning on the bureaucratic behavior has been proven, but is relatively small value. Similarly, the effect of controlling on bureaucratic behavior known influential relatively small. Occurred influence relatively large on the bureaucracy behavior to service quality.

Picture 4.1 : Model Results

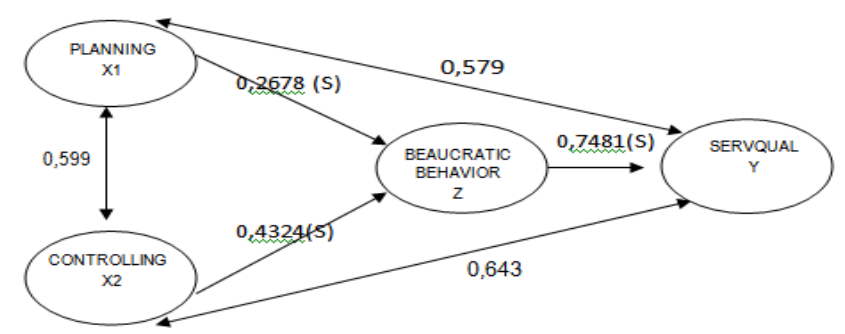

Description:

influence Pathways and there is a path relationship

There is only the connectivity, there is no pathway

\subsection{Discussion of Results}

Based on the analysis results can be known each characteristics variables and relationships between variables and influences. Characteristics of each variable can be expressed as follows: The relationship between variables in pathways according to the model was obtained following descriptive:

\subsubsection{Influence Planning on Controlling.}

Linearity regression analysis results prove that the two variables form the regression equation $\hat{\mathrm{x}}_{2}=$ $72,09+0,42 \mathrm{X}_{1}$ with a significant rate of regression. Linearity test proved that both variable linear with acceptable levels of significance. Thus the two data variables as having a relationship with nature, which means that any increase in plan then followed by a rise in the value of surveillance. Value of strength of the correlation between the variables 0.5986 , this value gives the sense that the degree of closeness of the relationship between planning and control is being and has the power relations by $59.86 \%$. This value has been tested with levels showed a significant correlation. The level of influence the planning of the supervision was not found because there is no direct influence. Based on the model, planning to supervision by other variables, the indirect effect is nil. Results of the analysis and opinion of the author that the planning and supervision have alignment (like two 
sides of a coin), it can be seen that the planning has relationships with supervision. Planning and supervision are the two sides that are related but have different roles, each has its own role in producing a value.

\subsubsection{Influence Planning on Behavior Bureaucracy.}

Linearity regression analysis results prove that the two variables form the regression equation $\hat{Z}=71,36$ $+0,454 X_{1}$ with a significant rate of regression. Linearity test proves that the two variables linearly with the level of significance accepted. Thus the two data variables as having a relationship with nature, which means that any increase in the plan to raise the value of bureaucratic behavior.

Value of the strength correlation between the variables 0.5042 , this value gives the sense that the degree of closeness of the relationship between planning and bureaucratic behavior is being, and has the power relations $25.42 \%$. This value has been tested with a significance level correlation. The level of direct influence planning on the bureaucratic behavior with coefficient 0.1350 .268 lane. Because the variables are not planning on bureaucratic behavior through other variables then there is no value of the indirect effect. Weak influence planning on the bureaucratic behavior caused by the service procedure does not go according to plan, each employee tends to wait, the distribution of employees in each unit of service is uneven so that each service unit has a different level of activity and result in poor service quality as a result of bureaucratic behavior that does not work to procedures according

\subsubsection{Influence Controlling on Bureaucracy Behavior}

Linearity regression analysis results prove that the two variables form the regression equation $\hat{\mathbf{Z}}=$ $42,05+0,71 \mathrm{X}_{2}$ with a regression level of significant.

Linearity test proves that the two linear variable with a significant level acceptable. Thus the two data variables as having a relationship with nature, which means that any increase in surveillance, then raise the value of bureaucratic behavior. Values of the strength of correlation between the variables 0.5793 , this value gives the sense that relationship between controlling on bureaucracy behavior is moderate and currently has the power relationship $33.56 \%$. This value has been tested with a significant correlation level.

The level of influence controlling on bureaucracy $25.3 \%$, with the value of the path coefficient 0.437 . The value is the result of direct influence. It is known by a causal model of bureaucratic behavior control over the of other variables are not passed then no indirect effect. The magnitude of the effect controlling on the bureaucratic behavior of oversight that have category are described that can be implemented through regulatory oversight, ongoing monitoring of how the Population and civil registry office is able to provide security for the norms in force in accordance with the organization goals

\subsubsection{Influence Bureaucracy Behavior on Service Quality}

Linearity regression analysis results prove that the two variables form the regression equation $\mathrm{Z}=$ $61.13+0.562$ with a significant rate of regression. Linearity test proves that the two linear variable with a significant level acceptable. Thus the two data variables as having a relationship with nature, which means that any increase in bureaucracy then raise the value of service quality. Value of the strength of correlation between the variables 0.7481 , this value gives the sense that the relationship between the bureaucracy level with the service quality is strong and has a power relations $55.97 \%$. This value has been tested with levels showed a significant correlation. The high impact bureaucratic behavior on service quality can be explained that the level of professionalism of employees sufficient, so service quality into something alien to the civil registry office employees deed. Bureaucratic behavior that is reflected through the attitude of government officials to the people who need the service to achieve service quality keywords. This is certainly supported by caring staff to serve society.

\subsection{5. . Influence Planning on Service Quality}

Linearity regression analysis results prove that the two variables form the regression equation $\hat{\mathbf{Y}}=$ $85,70+0,369 \mathrm{X}_{1}$ with a significant rate of regression. Linearity test proved that both variable linear with acceptable levels of significance. Thus both have variable data in line with the nature of the relationship, meaning that any increase in the planning of the increase occurred in service quality. Value of the strength of correlation between the variables at 0.5786 , this value gives the sense that the degree of closeness of the relationship between planning and service quality at population and civil registry office is being and has the power relations $33.48 \%$. This value has been tested with a significant level of correlation. The level of direct influence planning on service quality zero or does not exist, because there is no line between the two variables. But there are indirect effects through bureaucratic behavior $11.6 \%$. The results obtained are the indirect influence between planning on service quality in population and civil registration through bureaucracy. The results support the research Munhurrun, 2011, which declared successful in improving service quality. 


\subsubsection{Influence Controlling on Service Quality.}

Linearity regression analysis results prove that the two variables form the regression equation $\hat{\mathbf{Y}}=$ $60,01+0,590 \mathrm{X}_{2}$ with a significant rate of regression. Linearity test proved that both variable linear with acceptable levels of significance. Thus the two data variables as having a relationship with nature, which means that any increase in surveillance, then raise the value of service quality. Value of the strength of correlation between the variables 0.6431 , this value gives the sense that the level of controlling by the closeness of the relationship between service quality is strong, and has a power relations $26.60 \%$. This value has been tested with a significant level of correlation. Direct influence monitoring on the level of service quality zero or does not exist, because there is no line between the two variables. But there are indirect effects through bureaucratic behavior $21 \%$. The results obtained are the indirect influence between monitoring the services quality through the bureaucracy behavior.

\section{Conclusion.}

Indicators from planning is objectives, policies, procedures, evaluation, and program planning has established good that fact significant effect planning on the bureaucracy behavior in achieving service quality. While the policies, regulations, and procedures have been established oversight inherent in the facts that significantly influence bureaucracy behavior in the delivery of service quality to the people who need care in Population and Civil Registration Office. While fairness, caring, discipline, sensitivity, and responsibility have established bureaucracy that has proven to have a significant effect on service quality. Based on these conclusions, the researchers can develop a design concept that the planning and oversight of bureaucratic behavior determines the realization service quality of expected by the community.

\section{Reference}

[1] Soegandi, Lis. 2005. National Conference on Development of Public Services in the Field of Population, May 2002.

[2] Lovelock, Christopher. Product Plust, Mc. Graw-Hill, New York, 1994

[3] Albert, Weterson.1991 Planning. Development Jakarta: Indonesia Gallia

[4] Mathis Robert L. dan Jackson John H. 2006, Human Resource Management, translation. Salemba Four. Jakarta

[5] Maringan (2004) Basics of Administration and Management, Ghalia Jakarta Indonesia.

[6] Wisniewski, M. \& Donnelly, M. (1996), "Measuring service quality in the public sector: the potential for SERVQUAL", Total Quality Management, Vol. 7(4), p.357-365

[7] Rowley, Jennifer (1998) "Quality measurement in the public sector: Some perspectives from the service quality literature," Total Quality Management, vol. 9(2/3), p. 321-333

[8] Brysland, A. \& Curry, A. (2001) "Service Improvements in public services using SERVQUAL,"Managing Service Quality, vol. 11(6), p. 389-401

[9] Kokku Randheer,2011 Measuring Commuters' Perception on Service Quality Using SERVQUAL in Public Transportation, International Journal of Marketing Studies Vol. 3, No. 1; February 2011

[10] Munhurrun, Prabha Ramseook,. 2010. Service Quality In The Public Service. International Journal Of Management \& Marketing Research Volume 3 Number 1

[11] Robbins and Coulter. (2002). Management, 7 th edition. Prentice Hall,Inc.,New Jersey.

[12] Tjokroaminoto, Bintoro., 1974, Introduction to Administration Development LP3ES: Jakarta.

[13] Robbins, S.P., 2002. Organizational Behavior.: PT. Gramedia Group Index Jakarta

[14] M. Guy 2002. Auditing, Fifth Edition, Volume One, grants, Jakarta

[15] Harold Koontz and C.O’Donnel. (1984). Principles of Management . New York: Mc Graw-Hill Book Company.

[16] Terry, George And RG Franklin, 1982, Principles Of Management $8^{\text {th }}$ Edition Illinois, Richard. D. Join Inc. Home Wood.

[17] Kreitner, R., Kinicki, A. 2004. Organizational behavior. Sixth edition, (p. 710.) Boston: McGraw-Hill.

[18] Prederickson, George H., 1997. The Spirit of Public Administration. San Francisco: Jossey-Bass Publisher

[19] Hersey Paul, Blanchard Ken. Management of Organizational Behaviour, Prentice Hall Inc. Englewood Cliffs, New Jersey, 1982.

[20] Gibson, Ivancevich, Donelly. (1984). Organization and Management, translated by Djoeban Wahid. New York: McGraw.

[21] Gro"nroos, C. (1982). An applied service marketing theory. European Journal of Marketing, 16(7), 30-41.

[22] Berry, L., Zeithaml, V., and Parasuraman, A. (1985). Quality counts in services too. Business Horizons, May-June, 44-52.

[23] Parasuraman, A., Zeithaml, Valerie A. \& Berry, Leonard.L. (1985) "A conceptual model of service quality and its implications for future research," Journal of Marketing, vol. 49, p. 41-50

[24] Brady, M., and Cronin, J. (2001). Some new thoughts on conceptualizing perceived service quality: hierarchical approach. Journal of Marketing, 65(3), 34-49.

[25] Cronin, J.J. \& Taylor, S.A. (1992) “Measuring service quality: a re-examination and extension,” Journal of Marketing, vol. 56, p.55-68

[26] Parasuraman, A., Zeithaml, Valerie A. \& Berry, Leonard L. (1991) "Refinement and reassessment of the SERVQUAL scale," Journal of Retailing, vol. 67(4), p. 420-50

[27] Koelemeijer, K. (1991). Perceived customer service quality: issues on theory and measurement. 6th World Conference on Research in the Distributive Trades. The Hague, 68-76.

[28] Vandamme, R., and Leunis, J. (1993). Measuring service quality in the retail sector: an assessment and extension of SERVQUAL. 7th International Conference on Research in the Distributive Trades

[29] Parasuraman, A., Zeithaml, V., and Malhotra, A. (2005). E-S-QUAL: a multiple-item scale for assessing electronic service quality. Journal of Service Research, 7(3), 213-33.

[30] Parasuraman, A., Zeithaml, Valerie A. \& Berry, Leonard L. (1988) "SERVQUAL: a multiple-item scale for measuring consumer perceptions of service quality," Journal of Retailing, vol. 64(1), p. 12-40

[31] Miles \& Matlew B, A Michael Huberau, 1992, data qualitative analytical Translated; Tjeptjep R Rohidi, Jakarta, UI Press.

[32] Sugiyono. (2001) Research Methods Bandung: Alfabeta 